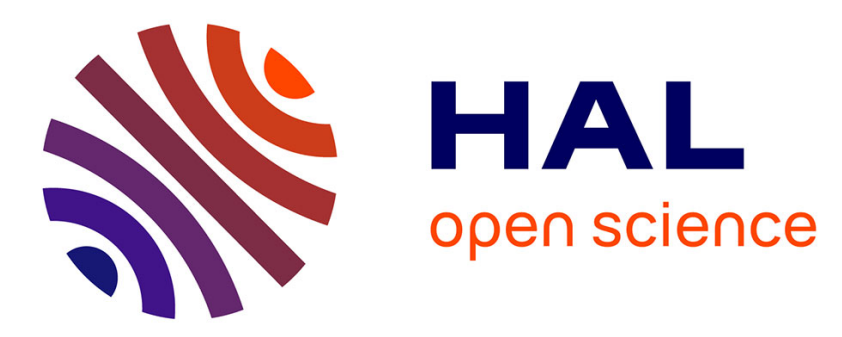

\title{
HOW DO BUSINESS SCHOOLS SUPPORT INTERNAL INNOVATION AND WORK ON THEIR STRATEGY AND THEIR REPUTATION? THE CASE OF RESPONSIBLE MANAGEMENT
}

Guénola Nonet, Kerul Kassel, Florence Rodhain

\section{- To cite this version:}

Guénola Nonet, Kerul Kassel, Florence Rodhain. HOW DO BUSINESS SCHOOLS SUPPORT INTERNAL INNOVATION AND WORK ON THEIR STRATEGY AND THEIR REPUTATION? THE CASE OF RESPONSIBLE MANAGEMENT. Journal of Innovation Economics \& Management, 2015, Intellectual Capital and Business Innovation, 2 (17), pp.68-98. 10.3917/jie.017.0069 . hal-01954798

\author{
HAL Id: hal-01954798 \\ https://hal.science/hal-01954798
}

Submitted on 2 Jan 2019

HAL is a multi-disciplinary open access archive for the deposit and dissemination of scientific research documents, whether they are published or not. The documents may come from teaching and research institutions in France or abroad, or from public or private research centers.
L'archive ouverte pluridisciplinaire HAL, est destinée au dépôt et à la diffusion de documents scientifiques de niveau recherche, publiés ou non, émanant des établissements d'enseignement et de recherche français ou étrangers, des laboratoires publics ou privés. 


\title{
HOW DO BUSINESS SCHOOLS SUPPORT INTERNAL INNOVATION AND WORK ON THEIR STRATEGY AND THEIR REPUTATION? THE CASE OF RESPONSIBLE MANAGEMENT
}

\author{
Guénola NONET \\ Nova Southeastern University Huizenga Business School \\ Fort Lauderdale, Florida, United States \\ gnonet@nova.edu \\ Kerul KASSEL \\ Fielding Graduate University \\ Santa Barbara, United States \\ kkassel@fielding.edu \\ Florence RODHAIN \\ Montpellier University \\ Montpellier, France \\ florence.rodhain@univ-montp2.fr
}

\section{INTRODUCTION: RM CHANGE AGENTS AND BUSINESS SCHOOLS' STRATEGY}

"Innovation is a continuous process. Firms constantly make changes to products and processes and collect new knowledge, and it is more difficult to measure a dynamic process than a static activity" (OECD, 2005, p.15). The ambition of this research is to understand and analyze the innovative and incremental processes created to engage the organisation and its stakeholders on issues of responsibility and sustainability. We introduce and analyze a number of incremental strategies created by the same actors to improve sustainability 
at their campus. We present these innovative strategies as "survival modes" adapted as a means to shift the main organizational strategy towards a responsible one. The actors described these incremental innovations as necessary tools to help them build and reinforce their projects towards a responsible management (RM) paradigm. Finally we conclude with a list of potential outcomes concerning Business School's (BS) reputation and strategy.

\section{WHAT IS RESPONSIBLE MANAGEMENT?}

Review of the literature reveals no consensus on a definition for responsible management, nor does the review of the Principles of Responsible Management Education (PRME). In 2007, the PRME Task Force (developed under the coordination of the United Nations Global Compact and leading academic institutions) developed a set of six principles "to lay the foundation for the global platform for responsible management education"1. Yet, the PRME six principles do not include a proper formal definition of RM.

As we enlarged the scope of our literature review to related topics, we found a variety of theories about corporate social responsibility (Klonoski, 1991; Melé, 2008; Martell, 2011), a number of approaches (Garriga, Melé, 2004; Winsor, 2006), and diverse descriptions of the models (for example, Caroll, 1999; Fisher, 2004). Corporate social responsibility can be called corporate conscience, corporate citizenship, social performance, or sustainable responsible business (Wood, 1991). Some authors note a difference between the Canadian (Montreal school of CSR), the Continental European, and the Anglo-Saxon approaches to CSR (Williams, Aiguilera, 2008, p. 453):

"The field of empirical CSR research generally has been hampered by the lack of a consistent definition of the construct of CSR, as well as its operationalization and measurement, as recently pointed out by Mc Williams, Siegel and Wright (2006) and Rodriguez, Siegel, Hillman and Eden (2006)".

These authors suggest that the lack of a universal definition about CSR affects research, in that there exist only a few empirical studies that show cross-national differences in managerial attitudes towards CSR. This lack of consistent findings might be explained, in part, by the lack of a universal definition of CSR (Williams, Aiguilera, 2008, pp. 467-468). In Europe, the debate regarding the definition of CSR is quite heterogeneous as well (Habisch, Jonker, Wegner, Schmidpeter, 2005). In addition, Kedge Business

1. UNPRME Website : http://www.unprme.org/the-6-principles/who-developed-prme/index.php 
School, has created a description of the responsible manager which serves the school as a guideline for their strategy:

"A responsible manager is not limited to the 'ecologist' connotation perceived sometimes when sustainable development is evoked, but includes ethical notions of social responsibility and corporate social and environmental responsibility, sustainable development (in its entirety), long-term performance, socially responsible investments, equity, diversity, management in complexity" (Kedge Business School, on-line edition).

In her dissertation, Guénola Nonet (2013, p. 138) defines the concept of responsible management according to business schools participants' answers as follows:

"Response-Able: To be able to respond.

- Based on individuals' self-awareness of their own values, and on their courage to stand for them.

- Participative, emerges through empowerment to build up a shared responsible vision.

- Responsible Management relies on all emotional competencies.

- Responds to the organization's goals while keeping holistic, macro and micro visions of the actions taken and of their consequences.

- Systemic decision-making grounded in the reality of life.

- Holistic consciousness of stakeholders and of consequences of present and future decision-making.

- Continuous theoretical and experiential learning and self-questioning".

\section{CONTEXT: BUSINESS SCHOOLS: A GROWING PHENOMENON}

The last two centuries, and in particular the last 50 years, have witnessed a new phenomenon: the growth of business schools (BSs). In response to increasing demand, business schools have proliferated and covered the globe:

"The twentieth century will be remembered for many great achievements-putting a man on the Moon, splitting the atom, and inventing the computer-but it is also the century that spawned the new academic discipline of management, which in turn created a multibillion-dollar global industry in management education" (Crainer, Dearlove, 1999, p. 11).

Prior to the last few decades there were only a small group of business schools, including Wharton (1881), Chicago (1890) and Harvard (1908), and an even smaller number of European business schools including Ecole 
Supérieure de Commerce of Paris (now ESCP-EAP) who claimed to be the oldest (1819), and HEC Paris (1881) (Clarke, 2008).

"Invented in the United States, the business school as we know is can be traced to the University of Pennsylvania's Wharton School, which was founded in 1881. The Wharton approach to business was numerical. Its bedrock was finance, and it was the management of money that was drummed into students from the earliest days. Other schools soon followed" (Baalen, Karsten, 2010, p.157).

During the nineteenth century, the idea was to promote a general education consisting of history, political science, economics, government policy etc. Pedagogical controversy grew later regarding the importance of codification and abstraction of management knowledge (Locke, 1989). Progressively in different parts on both sides of the Atlantic, in Europe and in the United States of America, an international movement took place. Pioneers in scientific management advocated a common body of knowledge. Frederick W. Taylor had already argued for the development of a "true science" (Taylor, 1911).

In the 1960s to the 1980s, the business school phenomenon was greatly concentrated in the Anglo-American countries. In the 1990s, this was further fuelled by the boom of new sectors within the US economy regenerating growth. The US took the lead in software and financial services. Rapidly the American influence grew in the global economy and business schools started spreading in Germany and wider European economies in the 1990s-2000s, and even in Japan despite cultural resistance (Clarke, 2008). The late $20^{\text {th }}$ century saw the growth of numerous academic business schools in the US and in Europe (Redlich, 1957, Locke, 1989; van Baalen, 1995).

"Business schools are the new corridor of power. They change people's lives. And we are not talking about someone undergoing a personal transformation in a leadership seminar. We are talking about people in factories in Illinois and Gdansk, Poland, changing the way they work and live because of business schools. President Clinton is not playing golf with Michael Porter simply for the fun of it. Porter has changed the way individuals, firms, and countries run themselves. His ideas on competitive strategies have been picked up and acted throughout the world" (Crainer, Dearlove, 1999, p. 3).

And yet, despite this growth success, the purpose of business schools remains largely debated (Hay, 2008).

"One fact that emerged after previous financial scandals was that most of the senior executives involved at Enron, Arthur Anderson and World Com had MBAs from business schools" (Parkes, Blewitt, 2011, p. 206). 


\section{WHAT IS NEEDED TO INTEGRATE RM INTO THE SCHOOLS' STRATEGY?}

In 2005 the retired CEO of Deloitte and Touche (Copeland, 2005) argued for the necessity of teaching ethics in accounting. Many authors with the same sentiment, writing within different fields, link irresponsible management in organizations to the education received at business schools (Mintzberg, 2004; Goshal, 2005; Burke, 2006; Rodhain, 2008; De Bry, Igalens, Peretti, 2010; Amman, Kerrets, Makau, Fenton, Zackariasson, Tripathi, 2012; Tripathi, Prakash, 2013, Waddock, Lozano, 2013) and ponder the main purpose of a business school:

"Throughout this explosive growth of the business school establishment, with these schools transforming from the poor relations among universities faculties to the cash-generating engines of university expansion, profound questions were recurrently asked about what the essential purpose of business schools was, and what they hope to achieve" (Clarke, 2008, p. 52).

There is very little empirical research concerning the needed changes at BSs to encourage RM. According to Martell (2011, p. 57), "if we want students to develop a social commitment, it is of the utmost importance that universities become living examples of this kind of action". Martell further explains the necessity of getting all BS stakeholders involved in the School's transformation towards RM: "our proposed model suggests a comprehensive plan of action, with an encompassing vision and a systemic approach, for the purpose of raising consciousness among members and stakeholders of the business school, of the many processes that they will have to commit to for achieving its transformation to become a socially responsible institution" (Martell, 2011, p. 173).

Those who conduct research about BSs and the shift to integrate RM topics and strategies will be familiar with this question: How do BSs support $R M$ agents' strategies towards RM? Shifting toward RM in BSs is not simply a matter of adding a course or two. In practice, the integration of RM into curriculum and institutional identity can be perceived either as threatening (for mainstream business teachers and courses, as well as for the schools' administration) or as a needed change that should be encouraged. Where some BSs are very driven to embed RM concepts, theories, and case studies, others struggle with it. As a direct consequence, those individuals in charge of RM or who aim at developing innovative education as well as strategies to encourage sustainability and responsibility face different tensions inside the school. As a result they will tend to innovate to support the development of a responsible strategy. To answer how BSs support RM agents' strategies, we researched the following sub-questions: 
- Do RM proponents need to innovate to get their institution to integrate RM into the BS curricula and main strategy? If so, why?

- What best practices inform the process of integrating RM into BS curricula \& strategy?

\section{METHODOLOGY AND DATA ANALYSIS}

To understand how RM change agents working at BSs are perceived and the type of strategy they develop towards responsible campuses, we have conducted an exploratory study adapted from Grounded Theory (Glaser, Strauss, 1967). Our research is based on emerging issues from field research that have none or very few echoes in literature. The main idea is not to try to prove an existing theory but to allow the theory to emerge from the fieldwork. Furthermore, Grounded Theory helps in creating new theories regarding empirical emerging phenomenon or may help to bring a new understanding to these phenomena (Guillemette, 2006).

Our study began with visits to or interviews with individuals at eight European BSs: five French members of the Conférence des Grandes Ecoles, two British business schools and one Dutch school, all three of which are ranked among the top European BSs (Financial Times). The BSs visited were selected based on an analysis, explained below, of the Financial Times rankings which classifies BSs annually ${ }^{2}$. Their Masters ranking was only used to access a list of European BSs offering Masters Degrees in Business Administration. We then evaluated each school on the list to determine whether they had created a Masters program fully focused on RM.

Although the Financial Times rankings are criticized for contributing to the current failure of BSs in creating a culture of RM (AACSB International, 2005; Hazlehurst, 2011; Burgess, Shaw, 2010), the FT ratings have been used for previous research on ethics, CSR and Sustainability education (Christensen, Peirce, Hartman, Hoffman, Carrier, 2007, p. 350):

The Financial Times rating "considers a large number of global programs than other ranking entities such as Business Week, the Wall Street Journal, and Forbes magazine. Given its longer history, the Financial Times ratings would have a greater potential for name recognition and for including exemplary programs in Asia, Europe, and Latin and Ibero America".

Semi-guided interviews were conducted with a number of the individuals involved at the BS to help transform its curricula and its strategy towards

2. http://rankings.ft.com/businessschoolrankings/ 
RM. The guideline evolved through time as we learned from our first experiences and adapted our questions, to deepen and verify our findings or to broaden our research. Generally, we received very positive feedback from all our respondents. The analysis and results of this research are based on primary data (In total, 17 interviews were conducted). The interviews were mostly face to face (13 out of 17) and lasted between 30 to 120 minutes in length and were conducted from September 2011 until March 2013 with professors involved in responsible and sustainable management on the campus. These professors also happen to be co-directors of the visited Masters programs. Interviews were conducted with administration such as directors of sustainability or Chief Sustainability Officer, as well. These interviews varied according to the respondent.

Also interviewed were 12 participants involved in RM for their BS. Four additional interviews were conducted between November 2012 and March 2013. The most recent interviews were conducted with sustainability officers working for BSs, universities, or Engineering schools. These schools are part of a French national group, Conférence des Grandes Ecoles. As members of this Conference, the participants meet annually to share about their progress, difficulties, and best practices in bringing RM to their schools. Our results indicate that their difficulties and level of innovation are similar and comparable despite some differences concerning their roles, introduced in Figure 1.

Figure 1 - Grid summarizing 17 interviews

\begin{tabular}{|l|l|l|l|l|}
\hline Respondents & \multicolumn{1}{|c|}{ Role } & \multicolumn{1}{c|}{ School } & \multicolumn{1}{c|}{ Time } & \multicolumn{1}{c|}{ Date } \\
\hline Respondent 1 & $\begin{array}{l}\text { Professor of } \\
\text { Business Society } \\
\text { Management - Climate } \\
\text { Chair }\end{array}$ & $\begin{array}{l}\text { Dutch Business } \\
\text { School/university }\end{array}$ & $60 \mathrm{mn}$ & October 2011 \\
\hline Respondent 2 & $\begin{array}{l}\text { Professor and Master } \\
\text { co-founder }\end{array}$ & UK BS & $90 \mathrm{mn}$ & September 2011 \\
\hline Respondent 3 & $\begin{array}{l}\text { Sustainability } \\
\text { Programme Coordinator }\end{array}$ & UK BS & $30 \mathrm{mn}$ & January 2012 \\
\hline Respondent 4 & $\begin{array}{l}\text { Campus Sustainability } \\
\text { Officer \& Professor }\end{array}$ & $\begin{array}{l}\text { Dutch Business } \\
\text { School/University }\end{array}$ & $90 \mathrm{mn}$ & October 2010 \\
\hline Respondent 5 & Sustainability Director & UK BS & $60 \mathrm{mn}$ & January 2012 \\
\hline Respondent 6 & $\begin{array}{l}\text { Chief Sustainability } \\
\text { Officer }\end{array}$ & UK BS & $90 \mathrm{mn}$ & January 2012 \\
\hline Respondent 7 & CSR Director & French BS & $50 \mathrm{mn}$ & January 2012 \\
\hline Respondent 8 & $\begin{array}{l}\text { Master founder \& } \\
\text { Professor, alternative } \\
\text { Management }\end{array}$ & French BS & $120 \mathrm{mn}$ & March 2012 \\
\hline Respondent 9 & $\begin{array}{l}\text { Master Co-Director, } \\
\text { sustainable management }\end{array}$ & French BS & $2 \times 120 \mathrm{mn}$ & $\begin{array}{l}\text { September } 2011 \\
\text { March 2012 }\end{array}$ \\
\hline
\end{tabular}




\begin{tabular}{|c|c|c|c|c|}
\hline Respondent 10 & $\begin{array}{l}\text { Assistant Professor, } \\
\text { Sustainable Management }\end{array}$ & $\begin{array}{l}\text { Dutch BS/ } \\
\text { University }\end{array}$ & $2 \times 120 \mathrm{mn}$ & $\begin{array}{l}\text { April } 2011 \\
\text { October } 2011\end{array}$ \\
\hline Respondent 11 & $\begin{array}{l}\text { Master Programme + } \\
\text { chair Coordinator }\end{array}$ & $\begin{array}{l}\text { Dutch BS/ } \\
\text { university }\end{array}$ & $90 \mathrm{mn}$ & October 2011 \\
\hline Respondent 12 & $\begin{array}{l}\text { Master co-founder \& } \\
\text { director }\end{array}$ & $\begin{array}{l}\text { School of } \\
\text { Management/ } \\
\text { university }\end{array}$ & $90 \mathrm{mn}$ & September 2011 \\
\hline Respondent 13 & $\begin{array}{l}\text { Sustainability \& Quality } \\
\text { director }\end{array}$ & $\begin{array}{l}\text { French Engineer } \\
\text { School }\end{array}$ & $60 \mathrm{mn}$ & March 2013 \\
\hline Respondent 14 & $\begin{array}{l}\text { CSR, Ethics and HR } \\
\text { Director }\end{array}$ & French BS & $60 \mathrm{mn}$ & December 2012 \\
\hline Respondent 15 & Sustainability Director & $\begin{array}{l}\text { French University } \\
\text { (business \& } \\
\text { engineering) }\end{array}$ & $50 \mathrm{mn}$ & November 2012 \\
\hline Respondent 16 & $\begin{array}{l}\text { Sustainability and Quality } \\
\text { Director }\end{array}$ & $\begin{array}{l}\text { French - Engineer } \\
\text { School }\end{array}$ & $65 \mathrm{mn}$ & January 2013 \\
\hline Respondent 17 & $\begin{array}{l}\text { MBA Programme } \\
\text { Coordinator }\end{array}$ & Dutch BS & $30 \mathrm{mn}$ & October 2011 \\
\hline
\end{tabular}

The type of questions asked during the interviews are summarized in Figure 2:

Figure 2 - Interviews questions about the school strategy and RM

\section{Questions about the strategy of the school towards responsible management:}

Respondent: Profile of the respondent, time allocated to the mission, formal job position $\mathcal{E}$ motivations for current responsible management mission,

School: History of the school, founders,

Main Strategy: school vision, school experience, main school's strategy, importance given to rankings $\mathcal{E}$ accreditations, financial funding, main decision makers, importance of the board, importance of the dean's profile,

Education: education innovation towards responsible management and initiators, Needs \& Practices: changes needed on the campus, good practices,

HR: recruitment process for job position towards responsible management,

Stakeholders: level of the board's support, level of the dean's support, students' interest, students' implication, suppliers flexibility, student's background, number of graduating students / year, organization chart at school, importance given to diversity in the recruitment. Responsible Strategy: responsible campus evaluation, resources allocated, press release and press impact, networking importance, specific strategy developed to enhance responsible management at the campus, school reputation.

We verified our results with most of our contacts after the codification process. During the entire study we did not experience resistance but felt 
welcomed by all those contacted, and continued to receive information from some individuals involved via BS Facebook accounts, Linkedin group sharing, and emails, yet for others no regular RM news or data was received (our findings indicated that these latter schools were less active in relation to their responsible strategy).

The methodology used to decode the data is content analysis. Several matrices have been created for the purpose of comparing results amongst schools. One of them is presented in Appendix (Part 4.2.2 of the Green Plan - section 4 focus on environmental management). We have used the Green Plan Outline "the Green Plan is designed to indicate objectives for each establishment, along with points that can progressively be implemented [...]"3 developed by Responsible Campus in France as a tool to compare each school's responsible strategy regarding two topics:

- Strategy \& Governance

- Environmental Management

At this stage, a relationship between categories was revealed and we integrated the literature to achieve theoretical saturation with the emerged theory (Idrees, 2011). "Bringing the literature into the writing not only demonstrates scholarliness but also allows for extending, validating, and refining knowledge in the field" (Strauss, Corbin, 1998, p. 52).

Each individual involved in responsible innovations describes some tensions regarding their missions (Nonet, Kassel, Meijs, 2014). Acting upon these difficulties, several incremental innovations are developed by different actors to create responsible changes at their BS. A theoretical discussion was developed to illustrate divergence between our empirical results and existing theoretical studies, and to present an emerging theory. As the interviewees often mention difficulties or challenges faced inside the school, we chose to offer anonymity to those we interviewed as well the name of the schools.

Previous research shows that the individuals involved in RM strategies for business schools face several types of tensions (Nonet et al, 2014: currently being published):

- Priority of ROI,

- Bottom-up innovation (less impactful than top down innovations),

- Limited resource allocation,

- Lack of knowledge and competencies,

- Transversal issues touching all parts of the school,

3. French Green Plan : http://www.developpement-durable.gouv.fr/Green-Plan.html 
- Limited commitment from the Top,

- Growing awareness facing denial.

Facing strong pressure from their business school's strategy, or the lack of understanding, the agents create a continuous innovative process to move towards responsible management. Within this process we were able to identify eight types of specific incremental and strategic innovations.

These tensions prompted the RM agents to employ innovative approaches and methods in order to sustain their programs and deliver on their roles. As the innovative approaches are intuitively or strategically developed by the RM agents to ensure that transformational changes do happen at the school, we called these innovations "survival strategies". Indeed, the RM agents do often feel and describe a sense of desperation and the need to defend their own legitimacy and the projects' legitimacy.

\section{INCREMENTAL INNOVATIONS TO ENCOURAGE RM}

Innovation can occur in any sector of our society, including services such as education (OECD, 2005). In the education sector, the OECD CERI (Centre for Educational research and Innovation) 2014 guideline for educational research and innovation describes the importance of innovation in education: "Education is a major component of government services: in 2010, public expenditure on educational institutions accounted for $5.5 \%$ of the national income on average for OECD countries. Innovations improving the effectiveness and efficiency of such large area of government spending could yield important benefits" (OECD, 2014, p. 21).

The guideline further explains the need for education to innovate to remain relevant: "education should remain relevant in the face of rapid changes to society and the national economy' (Barett, 1998, p.288). The educational sector should therefore 'introduce the necessary changes that permit it to adapt to societal needs"' (OECD, 2014, p. 21).

Defining innovation in education is a controversial topic within the literature. The OECD report suggests that "ideally innovation indicators in the education sector should be linked to specific social and educational objectives (e.g. learning outcomes, cost efficiency, equity, and public satisfaction). It should also be measured at different levels and, when they cannot be objective, measured according to different stakeholders perspectives" (OECD, 2014, p. 25).

The approach we have taken toward measuring educational innovation is close to that used by OECD CERID (2014): the adaptation of organisational 
change surveys to the educational sector. Based on Measuring the Dynamics of Organisation at Work (MEADOW Consortium, 2010) project in Europe, we adapt the definition of innovation as:

"the implementation of a new or significantly changed process, practice, organisation or marketing method observed at the education system level through micro-data collected within schools. The emphasis is particularly placed on change in practices. Given that we cannot directly observe whether these processes, practices and methods are 'improved', we have to depart from the Oslo Manual definition and use change as a proxy measure. It can be assumed that change occurs because of a belief that the new version is an improvement of some educational goal" (OECD, 2014, p. 27).

Within BSs, innovations towards RM are best described as a continuous process and therefore can be difficult to measure, especially as the individuals are involved in small incremental changes. Analysis of our interview data presents what we term the survival strategies developed by the RM agents and best described as a series of changes and improvements created to develop and ensure the growth of a RM strategy for the campus. In facing several tensions and difficulties in integrating RM at their schools, they feel the need to develop several innovative strategies to ensure that their goals are met and that their strategy to encourage RM would survive all barriers encountered. Depending on the level of flexibility inside the school, as well as the school's primary strategy, each agent involved in a responsible management strategy for the campus developed a specific survival mode.

The eight types of survival modes were encountered and described in the interviews:

1. Trojan horse strategy,

2. 'Voluntary' work,

3. Network and business alliances,

4. Talk the walk,

5. Publications and research,

6. Legitimacy and image,

7. Labels and rankings,

8. Group and sharing.

\section{Trojan horse strategy}

Throughout our research, it appeared that some of the individuals involved in responsible management developed some stratagems to cause a target to 
invite a "foe" into their securely protected space. The example below shows how a Masters program was created in a business school celebrated and renowned for its traditional courses in mainstream business.

"We were very aware that we were creating this course within one of the most highly rated schools of management in the country. There is no doubt that this appealed to some of our applicants, too. The title of their course may have made little sense to their employers and colleagues but the name of the university did. One of our original sponsors, Anita Roddick, described it as a Trojan horse strategy, and at times this combination amused us. However it also placed pressures on us. So I think we're more effective if we integrate with other more mainstream things" (Marshall et al, 2011, p.18).

One agent working on campus greening explained how it was at first difficult to get the business school's caterer to offer organic food. The caterer refused to adapt its offer. She started ordering food from an alternate caterer and persuaded a few other departments to do the same, eventually showing the school's official caterer the growing demand for organic offerings:

"I asked here at the facility management: can we order from outside? And they accepted, so we started doing it and other departments saw us eating organic: 'Oh, that's great stuff you have, where do you order that?' So after a while, a couple of departments and faculty were ordering catering from an external caterer. Then I talked with our caterer: 'do you know that this department and this department order organic lunches from an outside company?' 'What?' And then they immediately offered organic lunches and shortly after they started to offer some organic food in the canteen. It's funny how competition can bring a positive change!" (I.4)

Similarly, a professor who innovated by introducing a unique course taught outdoors at a botanical garden explained how she accidentally came to know that the dean was interested in ecology and that his interest helped to legitimate the course:

"There was some luck and as well seizing the moment! That's how I use my marketing side, to make sure that it works! [...] Then when I did the photo essay, I invited the dean of the university and a journalist of the School Magazine. And the dean saw the posters and he asked: 'are you doing stuff on industrial ecology?' And I said: 'No I'm not, but I'm doing stuff on sustainability!' And he said: 'well I did an undergrad on ecology and a Masters'. And nobody knew this! Nobody knew that our dean had actually studied sea turtles in California. And then he started to publicly speak out that he was an ecologist and I was like: 'what?' And I invited him to judge the first photos essay. So we gained immediate institutional support. That's how I played!" (I.1) 
Many persons involved in responsible management have had some luck at some point, but they have put a foot in the doorstep and have worked to be accepted. Very few courses are advertised using the words responsible management compared to the number of courses in which professors will bring in some reflections and discussions around these topics. This "Trojan horse strategy" is used by professors who feel that they cannot teach about responsible management as much as they would like to but who still want to share their beliefs and their knowledge with others. Their course outlines do not advertise anything about responsible management but the professors give examples, inviting the students to think differently:

"But even if you're in the mainstream, you can bring it in different ways, so next week I'm running 5 days for the MBA and although it has nothing to do with sustainability when I'll have to give examples, I'll talk about global warming and sustainable development because it's my area and I know that. I think when the participants feel that they're been lectured to or somehow campaigned at they react quite badly but if do you it carefully then they are interested" (I.5)

\section{"Voluntary" work}

Another survival mode used by the RM agents interviewed is "voluntary work". As responsible management is not always acknowledged as important, the agents lacked resources (time, money, staff). Yet, they balanced this lack of resources through voluntary work. One interviewee explained that she had rights for a sabbatical year and that she initially took it to write a book, but ended up networking to strengthen the curricula:

"I did work during half of my sabbatical year to develop our network, to get to know the alternative people, to strengthen our curricula. Hence there was a true dedication in us and I think in myself. As I had this sabbatical year, I could have used it to write, but I did not... [P]ersonal investment is highly important, the students are grateful. It is not easy to sacrifice ourselves!" (I.8)

When creating a Masters program, aiming at encouraging responsible management is not always part of the main strategy, and therefore few resources may be dedicated to it. In the following example, the administrative assistant did work for free during an entire year to support the creation of the school's RM Masters degree, on top of the job position she already had:

"We did manage to go live because of an administrative assistant. Her department was closing down and she was afraid of not having any activity and she was interested in our topics so she said 'I'll take it!' and 
eventually she has not been discharged from her previous work so she did manage both working positions at the same time...everything really happened based on our good will, on our work, a kind of voluntary work" (E.8).

This person explained to us that she started with a paid job position (part time), then her contract ended and she kept working for free: "My function of greening the campus was two paid days a week and now it's all voluntary." (I.4)

Another interviewee explained how she always ends up doing more than the 36 hours per week contract: "My contract is 36 hours per week [...] I work much more than 36 hours per week, of course" (I.7).

Some interviewees officially call for volunteers inside the school: "we created a carbon footprint, the committee to green the campus is made of students, faculties and staff - for this we ask volunteers. We called for the participation of motivated and dynamic students" (I.16).

Many interviewees mentioned the students' participation and help as well as the creation of voluntary groups to conduct these transformational changes: "That is how I got the idea, first as an informal working group to see if it would be possible to conduct a strategy to green our campus [...] it was difficult to ensure that the members were coming on a regular basis because they had already a full agenda" (I.15).

\section{Network - Business alliances}

All the Masters programs have worked deeply on developing their network and on creating alliances among businesses, NGOs, and governmental alliances. As they were lacking resources inside the school, the RM Masters cofounders went outside their institutions to build strategic alliances, gain knowledge, and access job or internships opportunities for their participants and resources:

"This year we have received a grant and sponsorships. Now they are on exchange at this $X$ school. In the end we have more resources than any other Masters program. That is so because we went out to look for sponsorship... I became an incredible networker, to enter, get to know the alternative stakeholders" (I.8).

This professor explained how doubtful she felt when facing business leaders, as the financial crisis was starting, assuming they would put their priority elsewhere:

"I don't know if you had a look at which CEOs are on our advisory board.

Many of them are involved in sustainability. I've presented to them a 
number of times and I asked them if they felt that sustainability was an invested growing strategic area. I asked that in the first part of the financial crisis, in 2008, and I thought it was quite a risky question, because they could have said 'well... let's sort out the bottom line first and come back to it later'. There were $€ 300$ billion involved in responsible management in that boardroom when I made that presentation and I received a unanimous support in investing in sustainability at the business school" (I.1).

Another type of networking that we encountered is between the professor, the course and the students. To make sure that the professors will get enough students registered, they deploy various strategies. Otherwise they could face difficulties in achieving sufficient enrolment. The professor quoted below explains how important it was to market the course and to imagine creative and appealing ways to attract students:

"And I thought: I need to find students. So because I come from a marketing background, we developed posters with my assistant, and her prior boyfriend was a designer. And we got the name and we said: We will market this course! Because I wanted 30 students! Because if you don't market, you get 5 or $10 \ldots$ So we went to all classes, you know we said wine and cheese, photo essay... all this great stuff... the arboretum (botanical garden)... We had packed! And I counted on 30 and we had 35 students walking in the first day! It was 6 years ago! We had extremely high evaluations!" (I.1)

\section{Talk the Walk}

Some of those interviewed developed an external strategy, becoming active with the media, and with non-governmental groups such as the United Nations Principles of Responsible Management Education (UN PRME). The school is then perceived as a campus which offers courses in responsible management. According to some study participants, they found this as the most effective way to persuade other faculty members to offer courses on responsible management:

"Generally our strategy is to make lots of noise out there with the UN, the media, with different sources or research so that the companies come to us and tell the faculty that they want sustainability on the program. That's a much more persuasive way of doing it" (I.6).

The following participant built a highly innovative course and kept it "quiet", not knowing if it would be accepted. However, due to short deadlines, no one noticed or said anything, likely because there was no oversight that might have determined how innovative and different it was: 
"So I did this course outline and I said you should check it with the chair of the department but of course they were under deadline and she said that she did check it and I don't know if she did it or not, I guess she did. But they put it in the brochure and it was there, they had to walk the talk!" (I.1)

In RM we often hear the fact that some companies walk the talk (showing commitment) and some others talk the walk (public relations greenwashing). Those companies aiming at deep change sometimes forget to communicate about their actions. The RM change agents have understood the necessity of employing both strategies: if they solely act and do not communicate, the scope of the changes will remain limited to a few departments. However if they manage to talk and get other stakeholders to communicate about it, then their fellow colleagues may begin to adapt this new identity and modify their culture, language, services and the courses they offer.

\section{Publications - Research}

Another survival mode that is mostly developed by faculty members involved in responsible management is research and publications. In each visited school, the co-founders of the RM Masters programs made a point of conducting research, communicating about their research, and getting published. One of the motivations is to legitimize the curricula, to show that it is grounded in theory, has solid theoretical background, and is scientifically valuable. As previously explored, these Masters programs have strategically established business alliances; they are strongly linked to the market and to real world practices. The studies are linked to management issues encountered in for-profit, non-profit, and governmental organizations. This study participant explains in detail how such research is developed:

"Aside from conducting rigorous research, another reason for establishing the departments was to conduct research commissioned by or in cooperation with the business sector. To facilitate this objective, in 2001 the board of the school funded the development of three research centres located at B-SM Department. These centres were in the field of international business-society management (SCOPE), business ethics (Ethicon), and communication (Corporate Communication Centre)" (Kaptein, Yip, 2010, p. 7).

One of the professors interviewed at another school explained how it was difficult to recruit a new co-director as one co-director was leaving:

"I have been looking for another professor to take over our co-director duties as he is leaving. I could not find any and this is for different reasons; 
the pedagogy is quite heavy and on top of that we have to communicate, to get published and I am really looking for a critical mind" (I.8).

The co-founder of one RM program created an Observatory website with free access to all their publications about responsible management. They publish about economics, politics, management, society, ecology, and values/ ethics matters. As one of their students commented during an additional interview, this website has been partly created to show what is published and done by the RM Masters program, for legitimacy purposes:

"The founder created this website. Not all Masters programs have such websites with references, literature review, and all the work done. She does it as much as possible to show what we produce. Through this website the entire world can access our work for free" (Masters student I.).

The co-founders of the another RM program wrote a book and have been planning on writing a second one about their pedagogy Leadership for sustainability, an action research approach (Marshall et al., 2011). In this book they present and comment upon 29 stories from MSc graduates, sharing the work of this "special band of people" and explain their "relevance to notions of leadership, practice, sustainability and change":

"Our primary purpose here is to make accounts of MSc in responsibility and Business Practice graduate's activities more widely available... and illustrate and expand notions of leadership for sustainability... Bringing this collection of stories together we have a range of readers in mind. We see them as activists of some kind, working in all sort of places... Some readers will also be in education, working with course participants on sustainability and social issues" (Marshall et al., 2011, pp. 1-2).

\section{Legitimacy - Image}

From the interviews we understood that one of the challenges for the RM agents is legitimacy, to develop a reputation that is positively perceived inside their business school. One of the co-founders of an RM Masters program explained that it took them a few years to reach legitimacy. Their approach was to build their identity; a task they believe has been successful because their school has been using their program for media purposes and other communications to promoting an image of innovation, showing they are developing new courses about responsible management:

"Nowadays we have reached a level of legitimacy where we can get closer to others such as another Masters in sustainable development. This was not possible 3 or 4 years ago, we were too fragile, we had not yet developed enough legitimacy, we were not 'installed'; now we are really 
settled in their minds. We are useful for the media strategy, it's clear, we have our spot in the school universe" (I.8).

Another professor explained that the school communicates about the RM program's work when it suits them. He acknowledged that the responsible management approach of their Masters program is not reflected in the business school's primary strategy but that the program is trotted out from time to time to burnish their reputation by illustrating the school's attention to responsible management issues:

"When it suits them they show us to say that our school is not a stock market accomplice but that we are working towards developing critical minds. We have been brought out again after the start of the [financial] crisis, when business schools were highly criticized. We had to develop a TV show and welcome a journalist from $x x$ to explain our RM Masters program. It is for these typical moments that they highlight our program. We are not within the main strategy of the school but we are not useless" (I.9).

External feedback can help the responsible management strategy to develop further as the board may then be prompted to feel that it burnishes the school's reputation:

"We have received some external feedback that influenced our responsible strategy. [D]ue to this feedback, the board found an interest: common knowledge and financial return, as some funding was promised from the Ministry of Agriculture. I do not think that any funding will ever be given but some have thought so and this was good for my strategy" (I.16).

\section{Labels - rankings}

A sixth survival mode is the use of labels and rankings. A director of sustainability or CSR might use it to convince their board or faculty members to shift towards a responsible management approach as a strategy to enhance reputation. This involves suggesting that, for the moment, business schools are free to innovate by integrating responsible management curricula and practices, but in a few years it will be mandatory, as a compulsory requirement to adhere to rankings criteria or any international agreements.

There are already growing slates of responsible management frameworks (PRME, EQUIS, AACSB, Aspen Institute). These requirements are not compulsory, but as promulgated by highly regarded groups they are useful in helping RM change agents convince their colleagues or supervisors about the desirability of moving towards a responsible campus embracing responsible management education. 
"The efforts of the school to concentrate and intensify the research in $B-S M$ were not in vain, as indicated by the results of the Aspen Institute's Beyond Grey Pinstripes ranking in 2005. The study showed that RSM was ranked. 16th in the world of business schools and third in Europe with respect to teaching and research in B-SM" (Kaptein and Yip, 2010, p. 8).

Another study participant mentioned legitimacy acquired through governmental feed-back:

"Nowadays, after four years I do not face the same reactions, I have acquired some legitimacy... [T]he Ministry of Agriculture gave this feedback: 'great improvements, efforts made"' (I.16).

However, it appears that the rankings based on voluntary reporting can be biased and more control seems to be needed to validate the schools' answers:

"In the last ASPEN ranking, we scored really high, but you know why? Because we mentioned all the electives that are offered by the main university and that our MBA students could have potentially taken. Aspen Grey Beyond Pinstripes did not ask if they had taken it but only if it were available on the courses agenda... Next year it will be different as Aspen will change their policy and ask if the students have really taken the courses, and you will see that we will score much lower in the ranking!"(I.10)

Some individuals tried to adopt the ISO certifications and gave up due to the high level of reporting constraints and their lack of time and resources to conduct such reporting on a regular basis:

"I thought of reaching ISO 14000, not so much because I'm an ISO fan but rather because I thought that for such a school [...] it would be a great learning session to have everyone involved and participating, but I soon realized that I had underestimated the difficulty because I had never done it previously. When we attain a certain stage, it is a real burden" (I.15).

\section{Group \& Sharing}

Some RM professors and directors decide to look for their answers outside the business school, joining a group and sharing their experiences with faculty and staff from other schools who would like to bring RM to their school but are facing their own difficulties in doing so. During the course of our study we discovered such groups. Most of them are nationally oriented and a few are international. 
In France: one group is a branch of the CGE Conférence des Grandes Ecoles (business schools, engineering schools, and higher education institutions offering other specialities) and it works closely with universities (CPU, Conférence des Présidents d'Université). The group was created in 2009 and organizes monthly meetings and as well an annual national summit ${ }^{4}$. They have designed tools to help campuses to become more responsible (the Green Plan of higher education institutions, Awareness-Raising Day on Sustainable Development, the Social Responsibility Conference).

The Netherlands: the DHO (Dutch National Network for Sustainable Development I Higher Education Curricula) was created in 1998 to develop competencies and incentives in the field of sustainable development. More than 1,000 educators, management education institutions, and representatives of companies take part in the network ${ }^{5}$. DHO has a role of helping to audit the campuses with the AISHE tool (Auditing Instrument for Sustainability in Higher Education), challenge experts, helping to develop trans-disciplinary education, and develop a future orientation.

The United Kingdom: the Environmental Association for Universities and Colleges (EAUC)

"was launched in 1996 with the aim of raising the profile of environmental management and facilitate improvement of environmental performance in member institutions. This was achieved through providing a forum for the sharing of experiences and information between individuals from different colleges and universities and disseminating good practices on environmental issues, campus greening, and curriculum greening"6.

Amongst other initiatives, EAUC launched the LIFE (Learning In Future Environments) programme and helps universities and colleges through a period of transition.

Global level: the Principles for Responsible Management Education (PRME), a United Nations supported initiative to promote and inspire responsible management education and research in academic institutions globally, was developed by representatives of the U.N. Global compact, AACSB International, the Association to Advance Collegiate Schools of Business, Aspen Institute's Business and Society Program, the European Foundation for Management Development, and the Global Responsible Leadership Initiative. The mission of the PRME initiative is to inspire

4. http://www.cge.asso.fr/nos-thematiques/societe-environnement

5. www.guninetwork.org/resources/good-practices/good-practices-listing/dutch-national-network-for-sustainable-

6. http://www.eauc.org.uk/who_we_are 
and champion responsible management education, research, and thought leadership globally? ${ }^{7}$ PRME has several working groups and chapters (anticorruption, gender equality, poverty, sharing information on progress, sustainable leadership in the era of climate change, executive degree programs, $50+20$ ), international national and regional meetings.

In a number of the study interviews the participants discussed their experience with one or another of these groups, and the strategies those groups suggested as best practices for mainstreaming RM education.

Legitimacy: The leadership of a national group can lend legitimacy to the strategies used by an RM professor in an effort to establish credibility and visibility:

"I invited the Director in charge of green campuses for an afternoon of work with all the departments. He explained more or less everything and from that point I started a unique close relationship with the group" (I.15).

As mentioned earlier, group participants may have developed a variety of tools helpful in building an internal strategy to establish legitimacy in the eyes of their board and their faculty members:

"To start the common day organized by the group, be a pilot school, the group helped me to put a foot in some doors [...] I really used their tool during my interviews with the board, to show a real methodology, something formal coming from the group" (I.16).

Create a demand by establishing a new identity: Another effective strategy is a school's involvement in the United Nations PRME, whether by a professor or a director of sustainability. For one interviewee, it helped him to bring the school to an international sustainability arena, among other advantages. One of the consequences is that businesses may then ask the school to deliver specific courses about responsible management, as they perceive the school to be a leader in that field.

"Our Director of the Centre for Business and Sustainability is sitting on the leadership team at the UN (PRME Principles of Responsible Management Education). He has been very effective. He's effective externally so he has put our school on the international sustainability stage. He has been very effective doing that, he does lots of work with the UN" (I.6).

Inspiration: Many participants experienced the advantage of benchmarking themselves against other schools, and receiving inspiration from others:

7. http://www.unprme.org/index.php 
"The added value of these sessions dedicated to share experiences is to see what is going on somewhere else and how to put ideas into practices, share and collect more ideas" (I.16).

Knowledge: Most of the participants mentioned their lack of knowledge and the benefits from learning throughout the group meetings: "Before 2009, my understanding of these issues was very limited. I had not read much and I had attended very few conferences. With the Group I did try to update my knowledge and to build up a network" (I.13).

"The added value is the knowledge, the courses. It's the courses that I don't have. When I go there I learn! For example when I was in XX school, I went to the course organized by the sub group a day before, and I learned a lot!" (I.15)

In summary, a group such as PRME helps their participants gain information and knowledge, benchmark their actions compared to others, legitimize their strategy within their business school while showing that they are part of a national/international network, and to create a new identity for their school, one that is active in the area of responsible management education.

The following figure summarizes the different "survival modes" encountered by study participants.

Figure 3 - Survival modes used to institutionalize responsible management programs at business schools

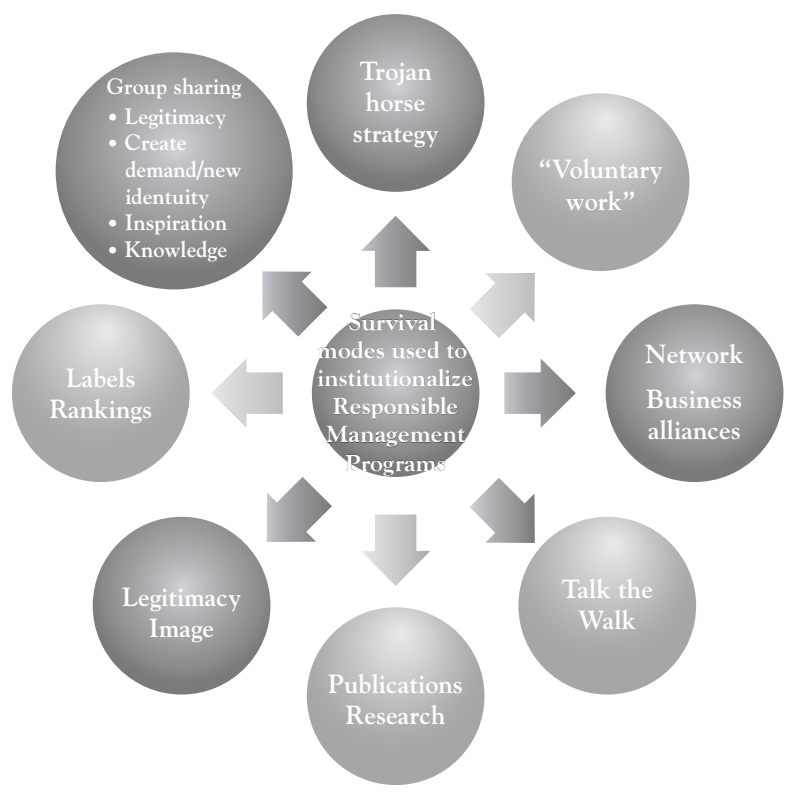




\section{CONCLUSION \& FURTHER RESEARCH}

The purpose of our research was to understand how BSs support RM agents' strategies towards RM Masters programs. To examine this trend, we studied two sub-questions:

- Do RM proponents need to innovate to get their institution to integrate RM into the BS curricula and main strategy? If so, why?

- What best practices inform the process of integrating RM into BS curricula \& strategy?

Our research adds to the understanding of how the primary strategy of BSs is related to RM education and strategic innovations. Our results are based on 17 interviews conducted with individuals involved in RM at their BS. Their titles vary, from Chief Sustainability Officer to Director of Sustainability, and some do not have a formal title but work strategically towards such RM changes. We described 7 types of innovations utilized by our study participants, which we labelled survival modes. Depending upon the level of flexibility inside the BS and its primary strategy, each person involved in a RM strategy for their campus developed a type of survival mode to ensure the success of their efforts.

These results are original as, to our knowledge; no previous empirical research has been conducted on this specific topic.

As to the limitations of this research, during our study were not able to directly interview the dean/CEO/director of the visited schools. This limits our understanding of the BS strategy. Additionally, the use of grounded theory may not result in as broad and detailed an understanding of all the data and the potential results as other possible methods of analysis. Over time, additional results may emerge from additional analysis.

Further research could be conducted to better understand the priorities and organizational strategy of the BS. Deans could be interviewed to evaluate their interest in supporting incremental strategic innovations towards RM.

Questions about the added value of the strategic innovation of group sharing are ripe for exploration, as well, since other organizations such as companies use them to move towards RM and collaborate with competitors to achieve responsible strategies.

Our research prompted additional research vectors, such as developing and understanding of the impact of faculty on BS evolution: throughout our studies the individuals interviewed mentioned their difficulty in communicating and getting the attention from their school's faculty. Further research is suggested on these specific questions: how to work with BS shareholders towards RM? What is the interest of faculty members in RM? What are the 
motivations that may trigger deans to work on various responsible innovations in their schools?

Our results reveal several potential strategic outcomes for the BS innovating to integrate RM in their strategy. The potential outcomes seem to be a direct consequence of innovating towards RM:

- Stakeholder management: Innovating towards RM seems to create a sense of cohesion outside the BS by connecting various stakeholders to act upon the mission

- Reputation: The strategic changes towards RM create both word of mouth and official press publicity that seem to be beneficial for the school's reputation.

- Accreditation: ACCSB emphasizes the importance of integrating RM in BS' strategy and curricula

- Differentiation: Working on issues such as RM seem to help create a new identity for the school

- Inner Cohesion: As innovating towards RM touches upon all BS departments and areas of the school, it seems to create a certain sense of cohesion towards this new component of the school's mission.

Further research is needed to understand and evaluate the potential outcomes of integrating RM in the BS' strategy. We suggest the following questions: what are the potential outcomes of innovating towards RM at a BS? How do these outcomes serve the main strategy of the school? What is the importance of RM for BS' reputation?

\section{REFERENCES}

AACSB International (2005), The Business School Rankings Dilemma, 2005 Report.

AMMAN, W., KERRETS, MAKAU, M., FENTON, P., ZACKARIASSON, P., TRIPATHI, S. (2012), New Perspectives on Management Education, New Delhi, Excel Books.

BAALEN, P., KARSTEN, L. (2010), The Social Shaping of the Early Business Schools in The Netherlands, Journal of Management History, 16(2), 153-173.

BURGESS, T., SHAW, N. (2010), Editorial Board Membership of Management and Business Journals: A Social Network Analysis Study of the Financial Times 40, British Journal of Management, 21, 627-648.

BURKE, R. (2006), A Role for Business Schools in Leadership, Futures and Ethics, Journal of Futures Studies, 10(4), 71-82.

CARROLL, A. B. (1999), Corporate Social Responsibility: Evolution of a Definitional Construct, Business $E$ Society, 38(3), 268-295.

CHRISTENSEN, L., PEIRCE, E., HARTMAN, L., HOFFMAN, M., CARRIER, J. (2007), Ethics, CSR, and Sustainability Education in the Financial Times Top 50 Global 
Business Schools: Baseline Data and Future Research Directions, Journal of Business Ethics, 73, 347-368.

CLARKE, T. (2008). The Business Schools: 50 years on, Education + Training, 50(1), 52-54.

CRAINER, S., DEARLOVE, D. (1999), Gravy Training - Inside the Business of Business Schools, San Francisco, Jossey-Bass books.

COPELAND, J. E. (2005), Ethics as an Imperative, Accounting Horizons, 9(1), 35-43.

DE BRY, F., IGALENS, J., PERETTI, J.-M. (2010), Éthique et responsabilité sociale, 78 experts témoignent, Paris, EMS.

FISHER, J. (2004), Social Responsibility and Ethics: Clarifying the Concepts, Journal of Business Ethics, 52(4), 391-400.

GARRIGA, E., MELE, D. (2004), Corporate Social Responsibility Theories: Mapping the Territory, Journal of Business Ethics, 53(1-2), 51-71.

GLASER, B., STRAUSS, A. (1967), The Discovery of Grounded Theory: Strategies for Qualitative Research, New Jersey, Aldine Transaction Publisher.

GOSHAL, S. (2005), Bad Management is Destroying Good Management Practices', Academy of Management Learning and Education, 4(1), 75-91.

GUILLEMETTE, F. (2006), L'approche de la Grounded Theory pour innover?, Recherches Qualitatives, 26(1), 32-50.

HABISCH, A., JONKER, J., WEGNER, M., SCHMIDPETER, R. (2005), Corporate Social Responsibility across Europe, Berlin, Springer.

HAY, M. (2008), Business Schools: A New Sense of Purpose, Journal of Management Development, 27(4), 371-378.

HAZLEHUST, J. (2011), Do the Rankings Really Help You Choose an MBA?, Management Today MBA $\mathcal{E}$ Business Education Guide, Spring.

IDREES, I, VASCONCELOS, A., COX, A. (2011), The Use of Grounded Theory in PhD Research in Knowledge Management, Aslib Proceedings, Emerald Issue, 63(2-3), 188-203.

KAPTEIN, M., YIP, G. S. (2010), The Future of Business School Research. CEMS Book 2010, Business Schools: Which Contribution to Society - Chapter from Rotterdam School of Management, Erasmus University.

KEDGE Business School (2009-2010), Responsible Managers, valuing diversity. Available at: http://www.euromed-management.com/en/RESEARCH\%20\%2526\%20VISION/Responsible\%20Managers [Accessed 28 September 2013]

KLONOSKI, R. J. (1991), Foundational Considerations in the Corporate Social Responsibility Debate, Business Horizons, 34(4), 9-18.

LOCKE, R. (1989), Management and Higher Education since 1940. The Influence of America and Japan on West Germany, Great Britain and France, Cambridge, iCambridge University Press.

MARSHALL, J., COLEMAN, G., REASON, P (2011), Leadership for Sustainability - An Action Research Approach, Sheffield, Greenleaf Publishing.

MARTELL SOTOMAYOR, J. (2011). Socially Responsible Business Schools: A Proposed Model, PhD thesis, ESADE Business School.

MEADOW Consortium (2010), The MEADOW Guidelines, Grigny, France. Available at http://meadow-project.eu/images/2013/meadowguidelines.pdf 
MELÉ, D. (2008), Corporate Social Responsibility Theories, in Crane, A., McWilliams, A., Matten, D., Moon, J., Siegel, D. (eds), The Oxford Handbook of Corporate Social Responsibility, New York, Oxford University Press, 47-82.

MINTZBERG, H. (2004), Managers not MBA, San Francisco, Berret-Koehler.

NONET, G. (2013), Responsible Management and Business Schools: Analysis of the Schools Strategy and the Education / Management Responsible et Business Schools: Une analyse par les strategies d'établissement et par les projets pédagogiques, $\mathrm{PhD}$ defended on November $27^{\text {th }} 2013$, Montpellier University, France.

NONET, G., KASSEL, K., MEIJS, L. (2014), Business Schools \& Responsible Management: A Long Road to Freedom, Nitte Management Review, 8(16).

NONET, G., RODHAIN, F. (2014), Responsible Management Strategy at Business Schools, A Case for Legitimacy? ADERSE 2014 Conference Reconnaissance et identification des parties prenantes.

OECD (2005), Oslo Manual, Guidelines for Collecting and Interpreting Innovation data, $3^{\text {rd }}$ Edition, Available at http://www.keepeek.com/Digital-Asset-Management/oecd/scienceand-technology/oslo-manual_9789264013100-en\#page13 [accessed online on July 9 2014] OECD (2014), Measuring Innovations in Education: A New Perspective, Educational Research and Innovation, OECD Publishing, Available at http://dx.doi.org/10/1787/9789264255696-en PARKES, C., BLEWITT, J. (2011), Ignorance was bliss, now I'm not ignorant and that is far more difficult. Transdisciplinary Learning and Reflexivity in Responsible Management Education, Journal of Global Responsibility, 2(2), 206-221.

REDLICH, F. (1957), Academic Education for Business. Its Development and Contribution of Ignaz Jastrow (1856-1937). In commemoration of the hundredth anniversary of Jastrow's birth, Business History Review, 31(1), Spring, 35-91.

RODHAIN, F. (2008), Le 'Je' et le décryptage du jeu mental comme préalable à une science en conscience, HDR Defended $9^{\text {th }}$ April 2008, Montpellier 2 University.

STRAUSS, A. CORBIN, J. (1998), Basics of Qualitative Research: Techniques and Procedures for Developing grounded Theory, Thousands Oaks, Sage.

TAYLOR, F. W. (1911), Principles of Scientific Management, New York, Harper \& Brothers. TRIPATHI, S., PRAKASH, A. (2013), Responsible Education for sustainable ISAE Approach, Inspirational Guide for the implementation of PRME - Learning to Go beyond ( $2^{\text {nd }}$ Edition). Available at: http://www.gseresearch.com/pages/prme-titles.aspx [Accessed 28 September 2013]

VAN BAALEN, P. J. (1995), Management en Hoger Onderwijs. De geschiedenis van het academisch management-onderwijs in Nederland, $\mathrm{PhD}$ thesis, Eburon, Delft.

WADDOCK, S. LOZANO, J. (2013), Developing More Holistic Management Education: Lessons Learned from Two Programs, Academy of Management Learning $\mathcal{E}$ Education 12(2) 265-284.

WILLIAMS, C., AIGUILERA, R. (2008), Corporate Social Responsibility in a Comparative Perspective, in The Oxford Handbook of Corporate Social Responsibility, Oxford, Oxford University Press, 453-472.

WINDSOR, D. (2006), Corporate Social Responsibility: Three Key Approaches, Journal of Management Studies, 43(1), 93-114.

WOOD, D. (1991), Corporate Social Performance Revisited, The Academy of Management Review, 16(4), 691-718. 
How do business schools support internal innovation...

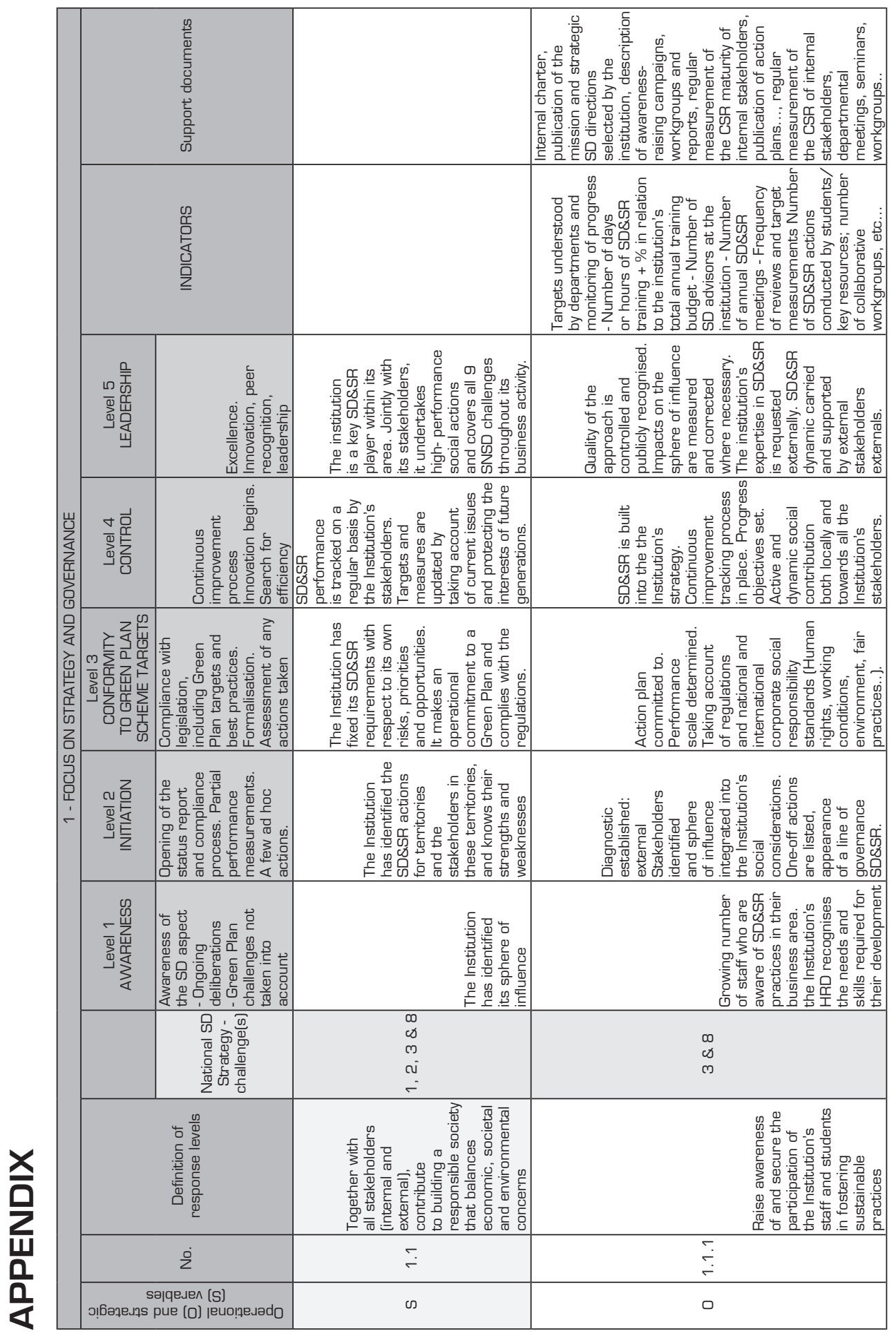

n०17 - Journal of Innovation Economics \& Management - 2015/2 


\begin{tabular}{|c|c|c|}
\hline 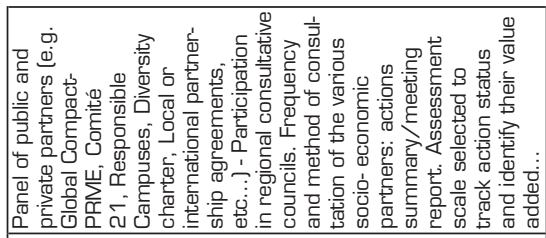 & & 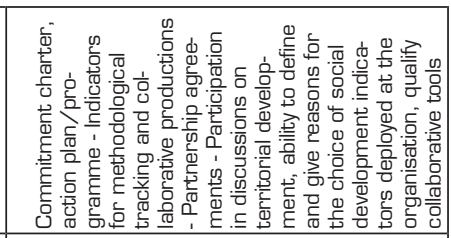 \\
\hline 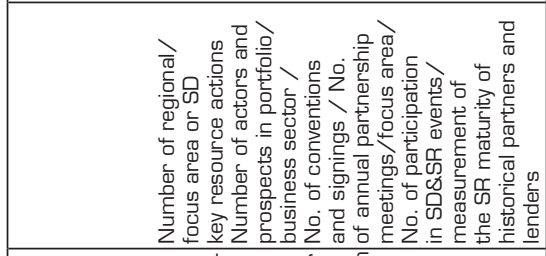 & & 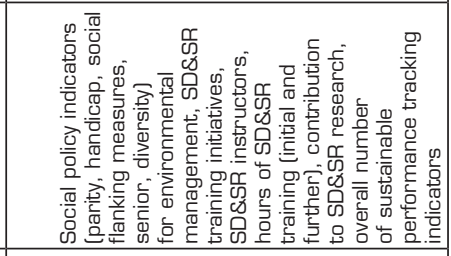 \\
\hline 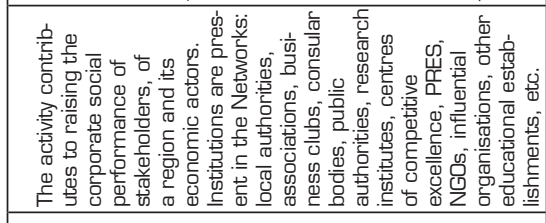 & 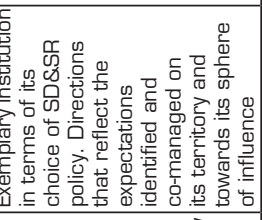 & 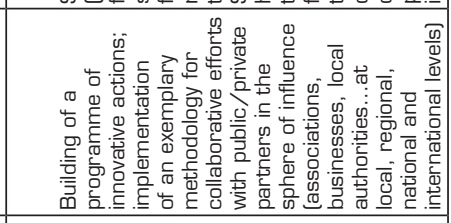 \\
\hline $\begin{array}{lll} & & \\
\end{array}$ & 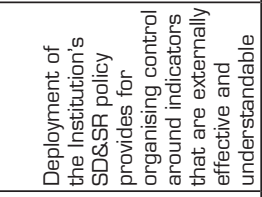 & 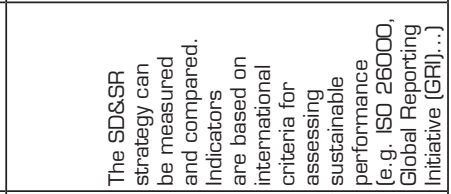 \\
\hline 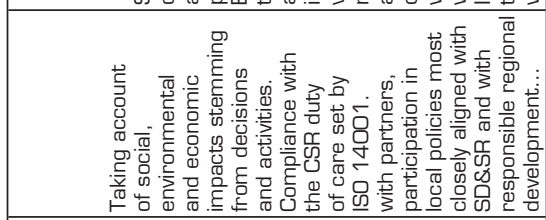 & 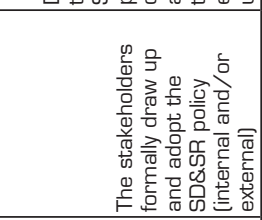 & 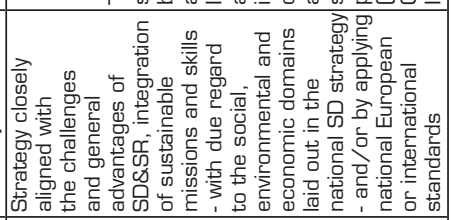 \\
\hline 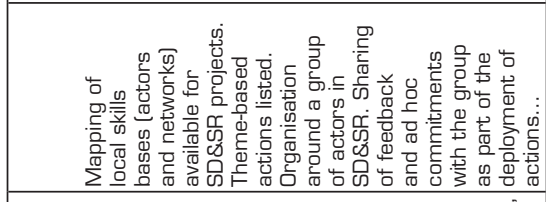 & 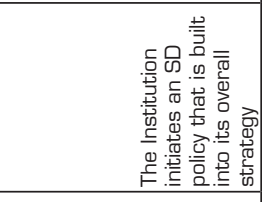 & 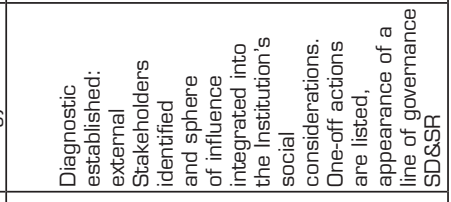 \\
\hline 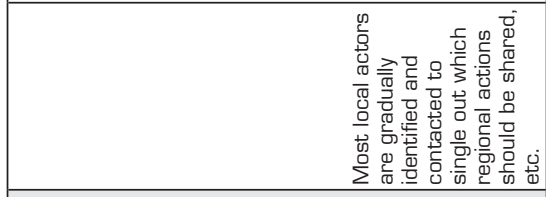 & 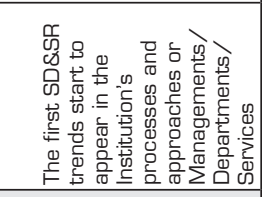 & 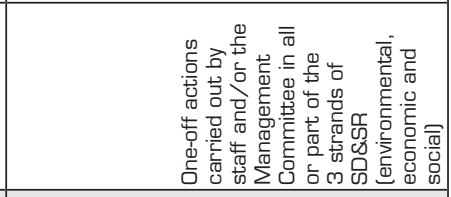 \\
\hline $\begin{array}{l}\text { W } \\
\infty \\
-\end{array}$ & 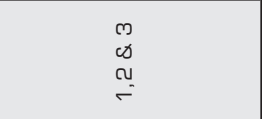 & ल \\
\hline 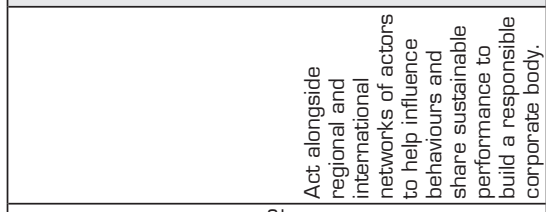 & 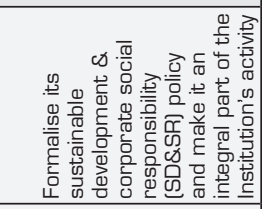 & 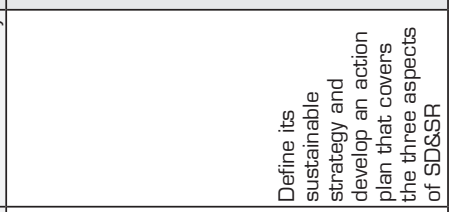 \\
\hline 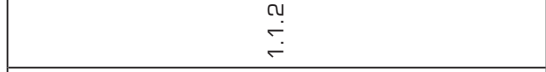 & $\stackrel{\leftrightarrow}{\leftarrow}$ & זָن \\
\hline ○ & $\omega$ & $\circ$ \\
\hline
\end{tabular}




\begin{tabular}{|c|c|c|}
\hline 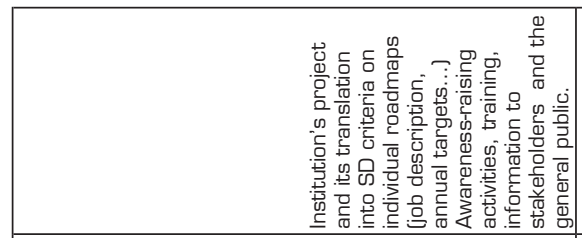 & 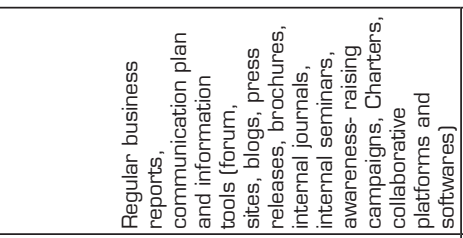 & \\
\hline 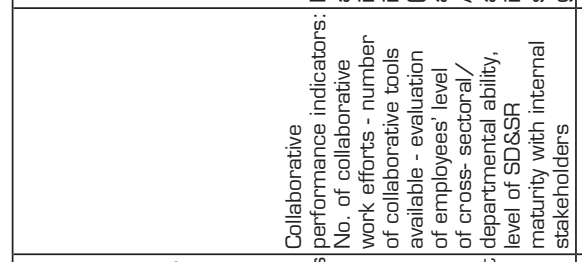 & 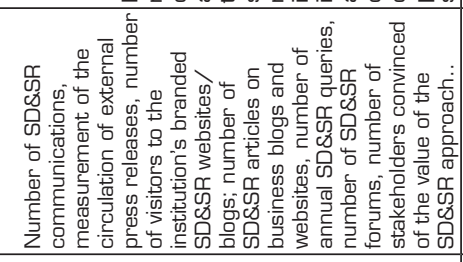 & \\
\hline 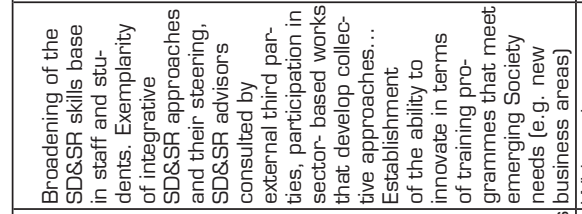 & 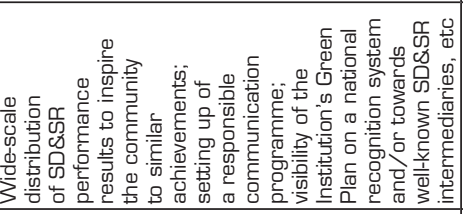 & 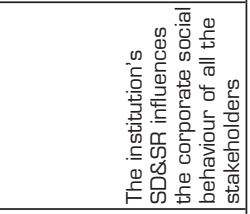 \\
\hline 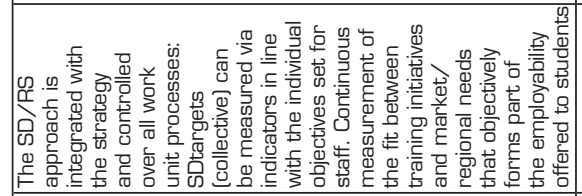 & 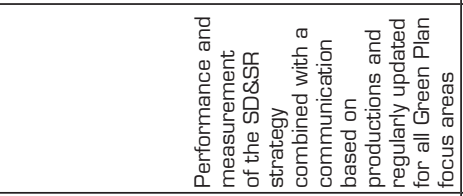 & 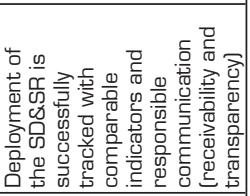 \\
\hline 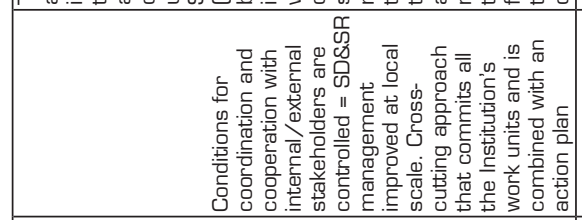 & 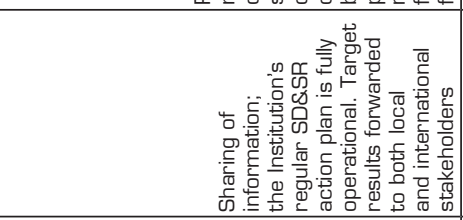 & 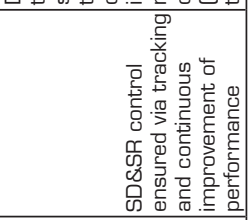 \\
\hline 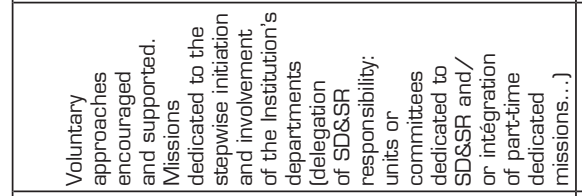 & 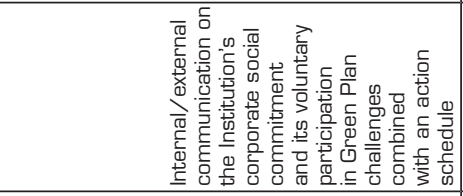 & 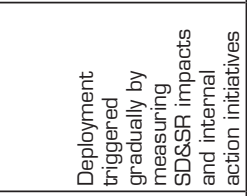 \\
\hline 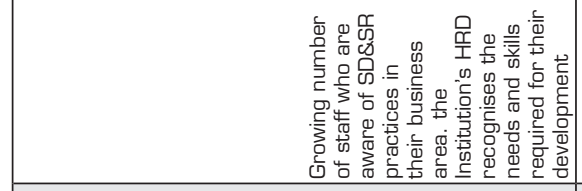 & 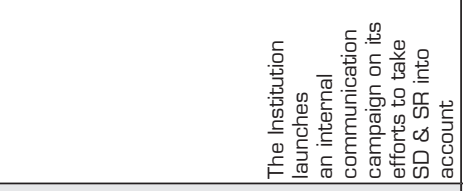 & 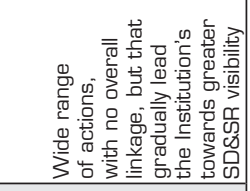 \\
\hline$r$ & $\begin{array}{l}m \\
\infty \\
-\end{array}$ & $\begin{array}{l}M \\
\infty \\
-\end{array}$ \\
\hline 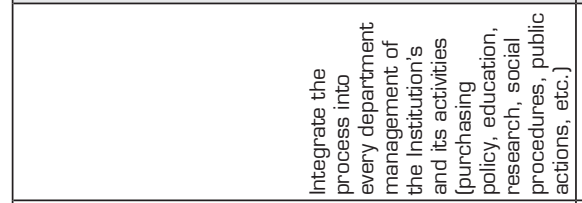 & 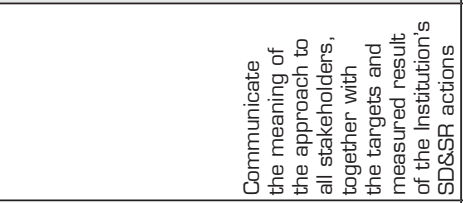 & 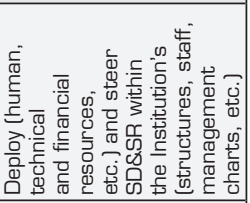 \\
\hline 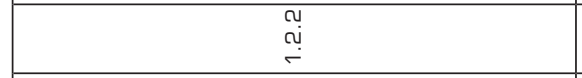 & 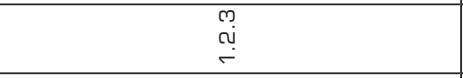 & $\stackrel{m}{\sim}$ \\
\hline ○ & ○ & ( \\
\hline
\end{tabular}


Guénola NDNET, Kerul KASSEL, Florence RDDHAIN

\begin{tabular}{|c|c|}
\hline 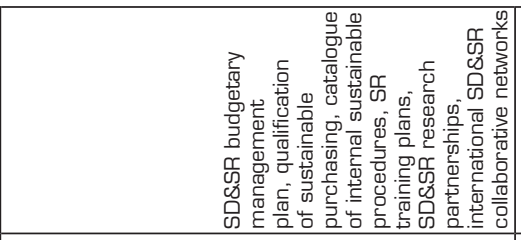 & 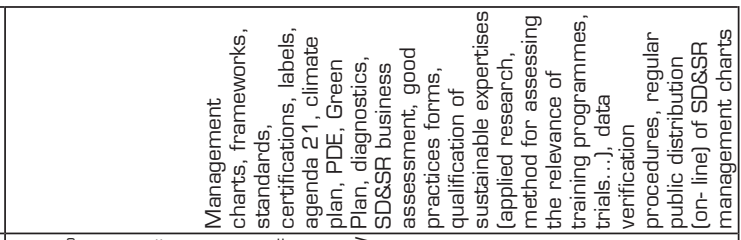 \\
\hline 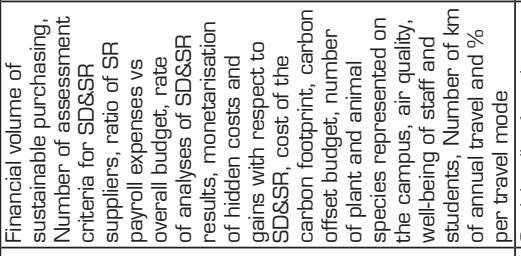 & 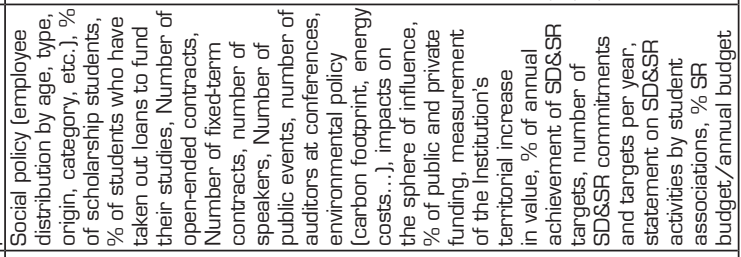 \\
\hline 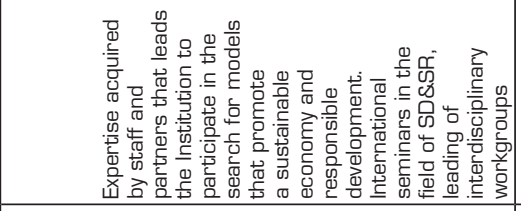 & 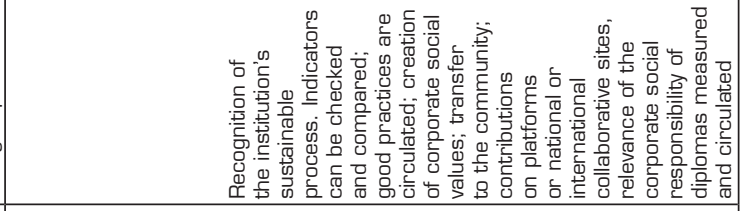 \\
\hline 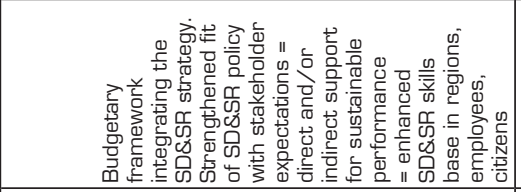 & 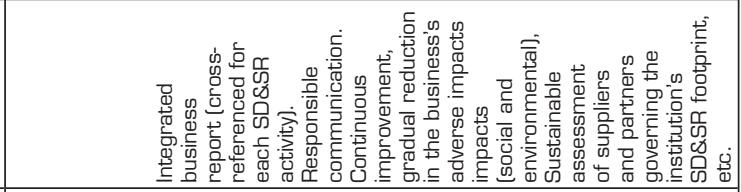 \\
\hline 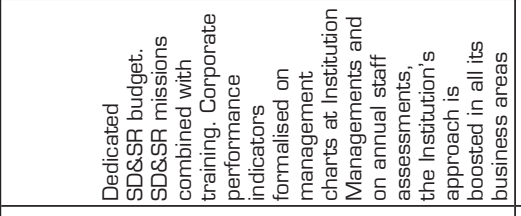 & 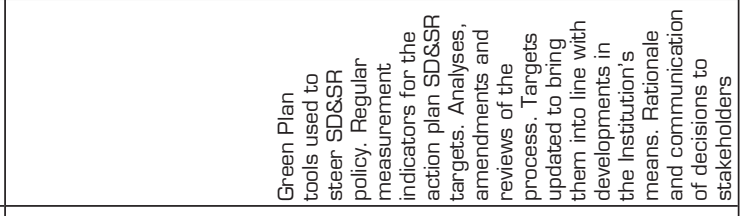 \\
\hline 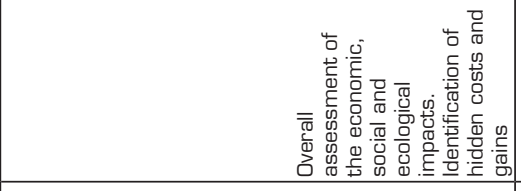 & 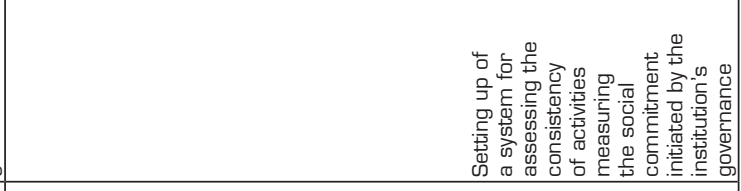 \\
\hline 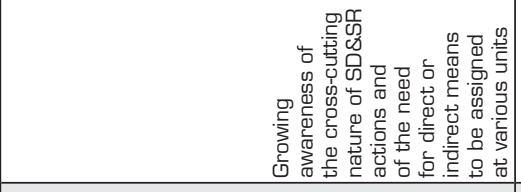 & 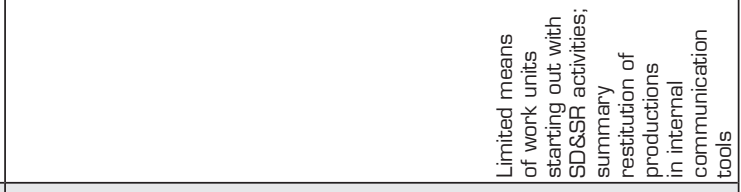 \\
\hline $\begin{array}{l}m \\
\infty \\
-\end{array}$ & $\begin{array}{l}m \\
\infty \\
r\end{array}$ \\
\hline 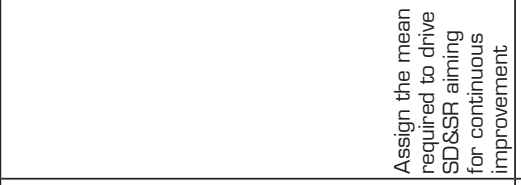 & 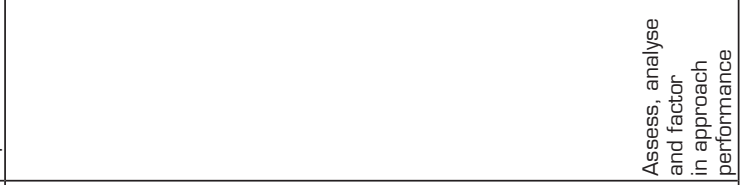 \\
\hline 户े & $\begin{array}{l}\text { ले } \\
\text { ले } \\
\end{array}$ \\
\hline ○ & ○ \\
\hline
\end{tabular}

